\title{
Method Validation of Chloramphenicol Analysis in the Shrimp Based on
} Diazotization Reaction

\author{
Abdul Wafi ${ }^{*}$, Ganden Supriyanto ${ }^{2,3}$, Tjitjik S. Tjahjandarie ${ }^{2}$ \\ ${ }^{1}$ Department of Pharmacy, Faculty of Medicine and Health Sciences, Universitas Islam Negeri Maulana Malik Ibrahim \\ Malang, Malang, 65143, Indonesia \\ ${ }^{2}$ Department of Chemistry, Faculty of Science and Technology, Airlangga University, Surabaya, 60115, Indonesia \\ ${ }^{3}$ Biosensor Laboratory, Institute of Tropical Disease, Airlangga University, Surabaya, 60115, In-donesia
}

Submitted 02 March 2020; Revised 14 March 2020; Accepted 28 March 2020; Published 10 June 2020

*Corresponding author:wafi@farmasi.uin-malang.ac.id

\begin{abstract}
A simple, rapid and precise spectrophotometric method has been developed and validated for the determination of Chloramphenicol (CAP) in the shrimp based on diazotization reaction at room temperature. The CAP was reduced by zinc powder and the diazotization reaction was carried out in the presence of $\mathrm{NaNO} 2$, bismuth nitrate pentahydrate as catalyst. The 2-napthol used as coupling agent to form a red-violet solution and the absorbance of azo dye solution was measured by UV-Vis spectrophotometer at $554 \mathrm{~nm}$. The method validation parameters including linearity, accuracy, precision, limit of detection (LOD) and limit of quantification (LOQ) have been investigated. The correlation coefficient (R2) was 0.996 for concentration range $0.70-4.65 \mu \mathrm{g} / \mathrm{mL}$. The LOD and LOQ were $0.36 \mu \mathrm{g} /$ $\mathrm{mL}$ and $1.19 \mu \mathrm{g} / \mathrm{mL}$. Accuracy and precision of the method were performed by spiking of CAP in the shrimp sample at concentration $1.16 ; 2.33 ; 3.49 \mu \mathrm{g} / \mathrm{mL}$. Analysis result showed that the accuracy and precision of the method were $92.77-97.37 \%$ and $0.21-2.39 \%$ respectively.
\end{abstract}

Keywords: Chloramphenicol, diazotization, method validation, shrimp, spectrophotometry

\section{Validasi Metode Analisis Kloramfenikol pada Udang Berbasis Reaksi Diazotasi}

\begin{abstract}
Abstrak
Sebuah metode yang sederhana, cepat dan presisi telah dikembangkan untuk penentuan kloramfenikol (CAP) pada udang berdasarkan reaksi diazotasi pada suhu kamar secara spektrofotometri. CAP direduksi dengan menggunakan serbuk seng $(\mathrm{Zn})$ dan reaksi diazotasi dilakukan dengan mereaksikan $\mathrm{NaNO} 2$, bismut (III) nitrat pentahidrat $(\mathrm{Bi}(\mathrm{NO} 3) 3.5 \mathrm{H} 2 \mathrm{O})$ sebagai katalis, dan $\beta$-naftol sebagai agen pengkopling untuk membentuk senyawa azo yang berwarna merah-ungu dan absorbansi diukur dengan spektrofotometer UV-Vis pada panjang gelombang $554 \mathrm{~nm}$. Parameter validasi yang ditentukan antara lain linearitas, akurasi, presisi, batas deteksi (LOD) dan batas kuantifikasi (LOQ). Koefisien korelasi (R2) yang diperoleh dalam penelitian ini sebesar 0,996 untuk rentang konsentrasi 0,70-4,65 $\mu \mathrm{g} / \mathrm{mL}$, LOD dan LOQ masing-masing sebesar $0,36 \mu \mathrm{g} / \mathrm{mL}$ dan $1,19 \mu \mathrm{g} / \mathrm{mL}$. CAP yang ditambahkan (spiking) ke sampel udang Litopenaeus Vanamie dan Litopenaeus Monodon sebesar 1,16; 2,33; 3,49 $\mu \mathrm{g} / \mathrm{mL}$. Hasil analisis menunjukkan akurasi dan presisi masing-masing berkisar 92,77-97,37 \% dan 0,21-2,39 $\%$.
\end{abstract}

Kata Kunci: Kloramfenikol, reaksi diazotasi, spektrofotometri, udang, validasi metode 


\section{Introduction}

Chloramphenicol
(GC-MS), ${ }^{3}$ Liquid Chromatog-raphyMass Spectrometry (LC-MS), ${ }^{4,5}$ En-zymeLinked Immunosorbent Assay (ELISA), ${ }^{6,7}$ High Performance Liquid Chromatography (HPLC) ${ }^{8}$ However, these methods involved special and high cost equipment. Hence, it is still necessary to develop different or simple approaches.

Spectrophotometric method is a very popular method or equipment owing to its easy-to-operate, specificity and low cost. In this work, an analytical protocol for determination of CAP in the shrimp based on diazotization reac-tion was established. The diazotization reaction occurred at room temperature in present of $\mathrm{Bi}\left(\mathrm{NO}_{3}\right)_{3} .5 \mathrm{H}_{2} \mathrm{O}$ as catalyst. 2-napthol used as coupling agent to form azo dye solution and the absorbance of azo dye solution was measured by UV-Vis spectrophotometer. The validation parameters such as linearity, precision, accuracy, LOD and LOQ of this method have been stud-ied.

\section{Method}

\subsection{Material}

CAP reference standard was purchased from Sigma Aldrich, Singapore. Bismuth nitrate pen-tahydrate $(\mathrm{Bi}(\mathrm{NO} 3) 3.5 \mathrm{H} 2 \mathrm{O})$ was purchased from Merck, Germany. Ethanol, sodium nitrite, ethyl acetate, concentrated hydrochloride acid, 2-napthol, zinc powder (Zn) were pure analytical grade. Litopenaeus vanamie and Litopenaeus monodon shrimp were obtained from local market in Surabaya, Indonesia.

\subsection{Preparation of reagent}

CAP $970 \mu \mathrm{g} / \mathrm{mL}$ : CAP powder $(0.097$

g) was weighed quantitatively and dissolved with ethanol. The solution was transferred to a $100 \mathrm{~mL}$ volumetric flask and made up with same diluent to mark.

NaNO2 8x10-2 M : NaNO2 powder $(0.5520 \mathrm{~g})$ was weighed quantitatively and dissolved in distilled water. The solution was trans-ferred to a $100 \mathrm{~mL}$ volumetric flask and made up same diluent to mark.

2-napthol 4x10-3 M : 2-napthol powder $(0.0576 \mathrm{~g})$ was weighed quantitatively and dissolved in $50 \mathrm{~mL}$ ethanol. The solution was 
transferred to a $100 \mathrm{~mL}$ volumetric flask and made up with distilled water to mark.

\subsection{Reduction of CAP}

A $2.50 \mathrm{~mL}$ of CAP solution $970 \mu \mathrm{g} / \mathrm{mL}$ was added with $1 \mathrm{~mL}$ distilled water, $1 \mathrm{~mL}$ of con-centrated hydrochloride acid and 0.15 $\mathrm{g}$ zinc powder, subsequently allowed for 15 minutes for reduction process. The solution was filtered and transferred quantitatively to a $25 \mathrm{~mL}$ volu-metric flask and made up with distilled water to mark to obtain the reduced CAP $97 \mu \mathrm{g} / \mathrm{mL}$.

\subsection{Diazotization reaction and formation of azo dye}

A $0.15 \mathrm{~g}$ of $\mathrm{Bi}(\mathrm{NO} 3) 3.5 \mathrm{H} 2 \mathrm{O}$ was added with 2,0 mL NaNO2 8x10-2 M. The solution was then added with $3 \mathrm{~mL}$ of reduced CAP solution and $3 \mathrm{~mL}$ 2-napthol $4 \times 10-3 \mathrm{M}$, allowed at room tem-perature for 8-9 minutes to form azo dye solu-tion.

\subsection{Spectrophotometric calibration curve}

The standard solutions for calibration curve were prepared by transferring $1.5 ; 3.0$; $5.0 ; 8.0$ and $10.0 \mathrm{~mL}$ of reduced CAP $97 \mu \mathrm{g} /$ $\mathrm{mL}$ in five different $25 \mathrm{~mL}$ volumetric flask and diluted with distilled water. The obtained standard solu-tions were $5.82 ; 11.63 ; 19.39$; $31.02 ; 38.78 \mu \mathrm{g} / \mathrm{mL}$.

Furthermore, the diazotization reaction was car-ried out for the five standard solutions. Subse-quently, the obtained azo dye solution of each concentration was transferred to a $25 \mathrm{~mL}$ volu-metric flask and diluted with distilled water to obtain CAP $0.70 ; 1.40$; $2.33 ; 3.72$ and $4.65 \mu \mathrm{g} / \mathrm{mL}$. The absorbance of azo dye solu-tions were measured with UV-Vis spectropho-tometer Shimadzu-1800 at $554 \mathrm{~nm}$.

\subsection{Application in shrimp (standard addition)}

After removing shells, Litopenaeus vanamie and Litopenaeus monodon shrimp were pulped. A $1.0 \mathrm{~g}$ homogenous shrimp was weighed and trans-ferred into three different glass beaker. Each glass beaker was added by $5,10,15 \mathrm{~mL}$ of re-duced CAP solution $97 \mu \mathrm{g} /$
$\mathrm{mL}$. Subsequently, $5.0 \mathrm{ml}$ of ethyl acetate, $1.00 \mathrm{~mL}$ of distilled wa-ter, $1.00 \mathrm{~mL}$ of concentrated hydrochloride acid and 0.15 of zinc powder were added. The solu-tion was filtered and transferred to a $50 \mathrm{~mL}$ volumetric flask and diluted with distilled water to obtain filtrate reduced CAP 9.7, 19.4 and $29.1 \mu \mathrm{g} /$ $\mathrm{mL}$. Furthermore, $3.00 \mathrm{~mL}$ of each fil-trate was pipetted and the diazotization reaction was carried out. The azo dye solution was transferred to $25 \mathrm{~mL}$ volumetric flask and dilut-ed with distilled water to obtain spiked CAP concentration of 1.16; 2.33 and $3.49 \mu \mathrm{g} /$ $\mathrm{mL}$, re-spectively. The absorbance of azo dye solution was measured with UV-Vis spectrophotometer Shimadzu-1800 at $554 \mathrm{~nm}$ at $554 \mathrm{~nm}$.

\section{Results}

3.1. Formation of azo dye

The principle reaction of this method is diazoti-zation and following by coupling reaction to form red-violet azo dye solution as shown in Figure 2.

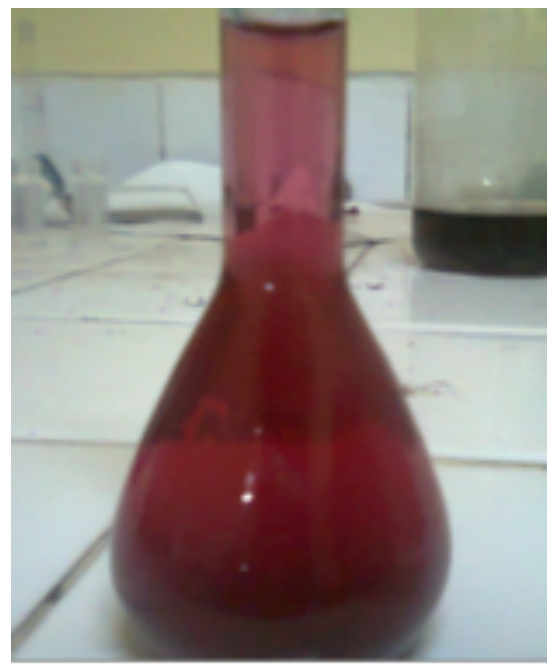

Figure 2. Photograph of Azo dye solution

\subsection{Method validation}

\section{A. Linearity}

The linearity was tested with the standard CAP concentration range of $0.70-$ $4.65 \mu \mathrm{g} / \mathrm{mL}$ as shown at Bable 1 .

The calibration curve, linear regression equa-tions, and correlation coefficient (R) are shown in Fig. 3. The result showed good linearity with correlation coefficient (R2) 
Table 1. Linearity result of CAP

\begin{tabular}{ccc}
\hline $\begin{array}{c}\text { CAP standard solution } \\
\text { No. }\end{array}$ & Concentration $(\mu \mathrm{g} / \mathrm{mL})$ & \\
\hline 1 & 0.70 & 0.220 \\
2 & 1.40 & 0.291 \\
3 & 2.33 & 0.342 \\
4 & 3.72 & 0.454 \\
5 & 4.65 & 0.523
\end{tabular}

0.996. The sensitivity of this method was 0.0749 .

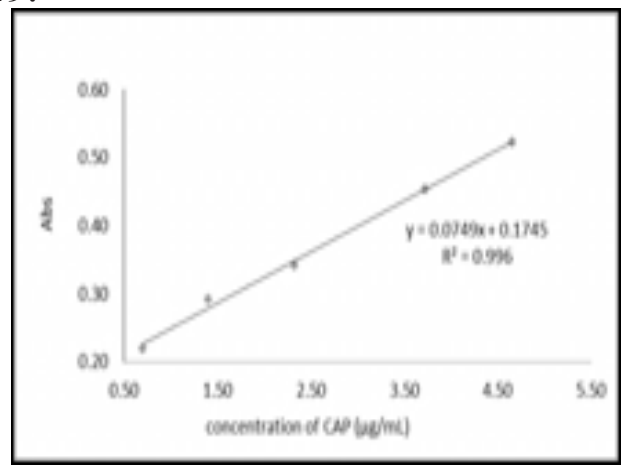

Figure 3. Calibration curve of CAP

B. Limit of detection and quantification

The limits of detection (LOD) and the limit of quantitation (LOQ) of the proposed method were $0.36 \mu \mathrm{g} / \mathrm{mL}$ and $1.19 \mu \mathrm{g} / \mathrm{mL}$, respectively as shown at Table 2 .

C. Accuracy and precision

The accuracy and precision of the proposed method were determined at three different con-centration of standard CAP including $1.16 ; 2.33 ; 3.49 \mu \mathrm{g} / \mathrm{mL}$. The results of accuracy and preci-sion were 92.77-97.37 $\%$ and $0.21-2.39$ as shown at Table 3.

\subsection{Application in shrimp}

The standard CAP was spiked in the shrimp sample at concentrations 1.16; $2.33 ; 3.49 \mu \mathrm{g} / \mathrm{mL}$, respectively. The result showed that the recover-ies of CAP spiked in Litopenaeus vanamie and Litopenaeus monodon were 92.64-97.37 \% and 93.83$104.25 \%$ respectively. The relative standard deviations (RSD) of CAP spiked in Litopenaeus vanamie and Litopenaeus monodon were $0.39-1.96 \%$ and $0.68-1.68 \%$ respectively as shown at Table 4 .

\section{Discussion}

In this study, the development of method for CAP analysis based on the diazotization

Table 2. LOD and LOQ of CAP

\begin{tabular}{|c|c|c|c|c|}
\hline $\mathrm{CAP}(\mu \mathrm{g} / \mathrm{mL})$ & $\hat{y} i^{a}$ & $\mathrm{yi}^{\mathrm{b}}$ & $\mathrm{LOD}(\mu \mathrm{g} / \mathrm{mL})$ & $\mathrm{LOQ}(\mu \mathrm{g} / \mathrm{mL})$ \\
\hline 0.70 & 0.227 & 0.220 & \multirow{5}{*}{0.36} & \multirow{5}{*}{1.19} \\
\hline 1.40 & 0.279 & 0.291 & & \\
\hline 2.33 & 0.349 & 0.342 & & \\
\hline 3.72 & 0.453 & 0.454 & & \\
\hline 4.65 & 0.523 & 0.523 & & \\
\hline
\end{tabular}

$\hat{\mathrm{yi}} \mathrm{i}^{\mathrm{a}}=\mathrm{abs}$ (theoretical); $\mathrm{yi}^{\mathrm{b}}=\mathrm{abs}$ (measurement)

Table 3. Accuracy and precision of CAP

\begin{tabular}{cccc}
\hline $\begin{array}{c}\mathrm{CAP}(\mu \mathrm{g} / \\
\mathrm{mL})\end{array}$ & $\begin{array}{c}\text { Detected }(\mu \mathrm{g} / \mathrm{mL}) \\
(\mathrm{n}=3)\end{array}$ & $\begin{array}{c}\text { Recovery } \\
(\%)\end{array}$ & $\begin{array}{c}\text { RSD } \\
(\%)\end{array}$ \\
1.16 & 1.08 & 92.77 & 0.49 \\
2.33 & 2.24 & 96.12 & 2.39 \\
3.49 & 3.40 & 97.37 & 0.21 \\
\hline
\end{tabular}


Table 4. The recoveries and RSD of CAP spiked in shrimp sample

\begin{tabular}{ccccc}
\hline Shrimp type & $\begin{array}{c}\text { Spiked level }(\mu \mathrm{g} / \\
\mathrm{mL})\end{array}$ & $\begin{array}{c}\text { Detected }(\mu \mathrm{g} / \mathrm{mL}) \\
(\mathrm{n}=3)\end{array}$ & $\begin{array}{c}\text { Recovery } \\
(\%)\end{array}$ & $\begin{array}{c}\text { RSD } \\
(\%)\end{array}$ \\
\hline Litopenaeus vanamie & 1.16 & 1.08 & 92.77 & 1.96 \\
& 2.33 & 2.24 & 96.12 & 1.19 \\
Litopenaeus monodon & 3.49 & 3.40 & 97.37 & 0.39 \\
& 1.16 & 1.21 & 104.25 & 1.68 \\
& 2.33 & 2.18 & 93.83 & 1.22 \\
& 3.49 & 3.38 & 96.98 & 0.68
\end{tabular}

reaction has been performed by reducing of nitro group to amine group on CAP structure using zinc powder. Reduced CAP acts as primary aro-matic amine for establishing the diazonium salt on diazotization reaction. Generally, diazonium salt has poor thermal stability and must be han-dled around $0-5^{\circ} \mathrm{C}$. But in this study, it kept sta-ble at room temperature because it was synthe-sized in presence of $\mathrm{Bi}\left(\mathrm{NO}_{3}\right)_{3} .5 \mathrm{H} 2 \mathrm{O}$ as catalyst. ${ }^{9}$

Generally, the reduced CAP, $\mathrm{NaNO}_{2}$, and $\mathrm{Bi}\left(\mathrm{NO}_{3}\right)_{3} \cdot 5 \mathrm{H}_{2} \mathrm{O}$ were mixed homogeneously for 1 minute to form a diazonium salt. Futher, the 2-napthol as a coupling agent was added to the diazonium salt and mixed homogeneously for 8-9 minutes to form a red-violet solution. The absorbance was measured by UV-Vis spectro-photometer at $554 \mathrm{~nm}$. The proposed reaction and optimization of each analytical parameter had been reported. ${ }^{10}$

In order to evaluate the performance of this method, the validation parameters such as linearity, precision, accuracy, LOD and LOQ have been evaluated. The result showed a good correlation coefficient $\left(\mathrm{R}_{2}=\right.$ 0.996) and sensitivity (0.0749). Alshirifi and
Alhameedi reported a spectrophotometric method of CAP analysis base on condensation reaction. The result showed an identical correlation coefficient $\left(\mathrm{R}_{2}=0.9983\right)$ and lower sensitivity (0.0577). However, the LOD and LOQ were lower compared with the present work with nearly 0.068 and 0.207 $\mu \mathrm{g} / \mathrm{mL}$, respectively. ${ }^{11} \mathrm{Al}-\mathrm{Abachi}$, et al., also proposed the determination of CAP in eye drop by using diazotization reaction in low tem-perature. The result exhibited a lower sensitivity compared with present method with nearly 0.0288 . However, it had a better (lower) LOD of $0.1334 \mu \mathrm{g} / \mathrm{mL} .{ }^{12}$ From this point of view, the present method exhibited a higher sensitivity and LOD.

The accuracy of this study was 92.77$97.37 \%$. The result showed a slightly lower accuracy compared with previous method with nearly $98.5-104.4 \%$ and $98.6-100 \%$. In addition, the precision of this study was 0.21 2.39\%. Alshirifi and Alhameedi; Al-Abachi, et al., have reported the precision of their methods were $0.23-0.67 \%$ and $0.67-0.91$ $\% .^{11,12}$ The com-paration of some parameters for CAP analysis in the proposed method and

Table 5. The comparison of CAP analysis in the proposed method and other literatures method

\begin{tabular}{|c|c|c|c|c|c|}
\hline $\begin{array}{l}\text { Analytical } \\
\text { parameters }\end{array}$ & $\begin{array}{l}\text { Proposed } \\
\text { Method }\end{array}$ & $\begin{array}{l}\text { Literature } \\
\text { Method } 8\end{array}$ & $\begin{array}{c}\text { Literature } \\
\text { Method } 13\end{array}$ & $\begin{array}{l}\text { Literature } \\
\text { Method } 13\end{array}$ & $\begin{array}{l}\text { Literature } \\
\text { Method } 14\end{array}$ \\
\hline Type of method & Diazotization & HPLC & Diazotization & Diazotization & Diazotization \\
\hline Reagent & 2-napthol & - & Imino dibenzyl & 3-amino phenol & $\begin{array}{l}\text { N-methyl } \\
\text { aniline }\end{array}$ \\
\hline$\lambda_{\max }(\mathrm{nm})$ & 554 & 225 & 590 & 470 & 504 \\
\hline Color of dye & red-violet & - & violet & orange & orange \\
\hline Temperature $\left({ }^{\circ} \mathrm{C}\right)$ & $\begin{array}{c}\text { room } \\
\text { temperature }\end{array}$ & 25 & $0-5$ & $0-5$ & $0-5$ \\
\hline Recovery (\%) & $92.77-97.37$ & 81.1 & - & - & - \\
\hline $\mathrm{LOD}(\mu \mathrm{g} / \mathrm{mL})$ & 0.36 & 0.024 & - & - & 100 \\
\hline
\end{tabular}


other previous method is shown at Table 5.

The standard additions method on the shrimp sam-ples (Litopenaeus vanamie and Litopenaeus monodon) was investigated to confirm the direct procedure. As shown in Table 4. The method ex-hibits a good accuracy (\% recovery) and precision (\%RSD) with nearly $92.77-104.25 \%$ and $0.39-1.96 \%$. It indicated no interferences appeared during preparation of samples. On other word, the method is reliable enough on the determination of CAP in the shrimp samples.

\section{Conclusions}

Aspectrophotometric method validation of CAP analysis based on simple diazotization reaction has been successfully performed. From the present study it can be concluded that the proposed meth-od was simple, rapid, precise and accurate.

\section{Acknowledgement}

Authors are very grateful to Analytical Laboratory of Chemistry Department of Airlangga University, Surabaya, Indonesia for providing the facilities to carry out this research work.

\section{Daftar Pustaka}

1. Yang S.Y.; Ho C.S.; Lee CL.; Shih B.Y.; Horng H.E.; Hong C.Y.; Yang H.C.; Chung Y.H.; Chen J.C.; Lin T.C.. Immunomagnetic Reduction Assay on Chloramphenicol Ex-tracted from Shrimp. Food Chem. (2012) 131 : 10211025.

2. Suseno, H., Hudiyono, S., \& Muslim, M. Elimination of Chloramphenicol by Tiger Shrimp (Penaeus monodon) and White Shrimp (Litopenaeus vannamei). HAYATI Journal of Biosciences, (2016) 23(3), 117-120.

3. Silva, L. T., Druzian, J. I., \& Da Silva, J. R. Optimization and intralaboratorial validation of method for analysis of chloramphenicol residues in goat milk by GC/ECD. Quimica Nova, (2010). 33(1), 90-96.

4. Ashraf, S. A., \& Azaz Ahmad Azad, Z. R. Development and validation of an
UPLC-ESI-MS/MS analytical method for the determination of streptomycin and dihy-drostreptomycin residues in honey. Bio-medical and Pharmacology Journal, (2017) 10(4), 1983-1992.

5. Kikuchi, H., Sakai, T., Teshima, R., Nemoto, S., \& Akiyama, H. Total determination of chloramphenicol residues in foods by liquid chromatography-tandem mass spec-trometry. Food Chemistry, (2017) 230, 589-593.

6. Scortichini G.; Annunziata L.; Haouet M.N.; Benedetti F.; Krusteva I.; Galarini R. ELISA Qualitative Screening Of Chloramphenicol in Muscle, Eggs, Honey and Milk. Anal. Chim. Acta (2015) 535 : 43-48.

7. Biernacki, B. ELISA validation and deter-mination of cut-off level for chlorampheni-col residues in honey. Bulletin of the Veter-inary Institute in Pulawy, (2015) 59(3), 353-356.

8. Kai Y.; Wang X.H.; Zhang W.; Yang L.; Liu P. Preparation of Molecularly Imprinted Microspheres for Solid-Phase Extraction Coupled with HPLC for Determination of the Florfenicol Residue in Milk, IJSID (2012) 2 (6) : 610-616.

9. Mirjalili F.; Bamoniri A.; Salehi N. $\mathrm{Bi}(\mathrm{NO} 3) 3.5 \mathrm{H} 2 \mathrm{O}$ : an Efficient Acidic Rea-gent for Synthesis Of Azo Dyes at Room Temperature. IJC (2012) 2(3) : 129-133.

10. Wafi A.; Supriyanto G.; Tjahjandarie T.S. A Novel Spectrophotometric Method for Determination of Chloramphenicol Based on Diazotization Reaction at Room Temper-ature. Indonesial J. Chem. (2016) 16(1) : 32-35

11. Alshirifi, A. N., \& Alhameedi, D. Y. New spectrophotometric determination of chlo-ramphenicol in pharmaceutical preparations based on condensation reaction with 1,2-naphthoquinone-4sulfonic acid (1,2 NQS) as reagent. International Journal of PharmTech Research, (2016) 9(9), 281-293.

12. Al-Abachi, M.Q.; Abed, S.S.; AlUzri, W.A.A.; Spectrophotometric Determination of Chloramphenicol 
in Pharmaceutical Preparations. Iraqi Na@onal Journal of Chemistry, (2014) 55: 231-242

13. Naik S.D.; Nagaraja P.; Yathirajan H.S.; Hemanthakumar M.S.; Mohan B.M. New Spectrophotometric Methods for the Quantitative Determination of Chloram- phenicol in Pharmaceuticals. J. Pharm. Chem. (2006) 40(10) : 576-581.

14. Shelke S.P.; Thorat M. An Alternative Spectroscopic Method for Chloramphenicol from Bulk Drug and Formulation. IJPSR (2013) 1(1) : 27-29. 